\title{
Analysis of mayor zinc sources in marine sediments of the estuarine zone in Aysén Fjord, Chile
}

\author{
Ramón Ahumada ${ }^{1}$, Elizabeth González ${ }^{1}$, Valentina Medina ${ }^{1}$ \& Anny Rudolph ${ }^{1}$ \\ ${ }^{1}$ Departamento de Química Ambiental, Facultad de Ciencias \\ Universidad Católica de la Santísima Concepción, Casilla 297, Concepción
}

\begin{abstract}
The present study determined the main sources of Zn enrichment at the head of Aysén Fjord. The study considered the analysis of the river sediments that enter the fjord (fluvial record), the marine sediments at the head of the fjord (estuarine area record), and the sediments from stations along the fjord (horizontal concentration gradient). The $\mathrm{Zn}$ content was analyzed, as were $\mathrm{Cd}, \mathrm{Cu}$, and $\mathrm{Pb}$ as references. A different chemical attack was performed in order to estimate the total $\mathrm{Zn}$ and a sequential extraction techniques to estimate the "species" or fractions. The quantification was done using a polarographic analyzer (POL 150) coupled to a Trace Lab 50TM with square wave voltammetry and standard addition. Moreover, the sediment grain size, total organic matter, total organic carbon, and total phosphorus were analyzed. The results confirmed the highest zinc concentrations in the surface sediments at the head of the fjord. The profiles showed the highest concentrations of $\mathrm{Zn}$ at the surface. The fractional chemical attack indicated that residual $\mathrm{Zn}(60-80 \%)$ was the most abundant fraction. The $\mathrm{Zn}$ fractions associated with oxy-hydroxides and organo-metallics were similar (10-20\%) and greater than the exchangeable fractions (5-10\%). The residual $\mathrm{Zn}$ was associated with the lithogenic fraction and the rest corresponded to fluvial contributions main baseline components, whereas the remaining inflow corresponded to contributions associated with fluvial, advective, and anthropogenic components at the head of the fjord. The identification of the sources of $\mathrm{Zn}$ enrichment provides information relevant for implementing management policies to protect the area and indicates the changes due to anthropogenic sources.
\end{abstract}

Key words: estuaries, sediments, Zn, anodic redissolving voltammetry, Aysén Fjord, Chile.

\section{Análisis de las principales fuentes de $\mathrm{Zn}$ en sedimentos marinos de la zona estuarial del fiordo Aysén, Chile}

RESUMEN. Se identificó las principales fuentes de Zn en la cabeza del fiordo Aysén. El estudio consideró el análisis de los sedimentos de los ríos que ingresan al fiordo (registro fluvial), del sedimento marino en la cabeza del fiordo (registro área estuarial) y de las estaciones situadas a lo largo del fiordo (gradiente horizontal de concentración). Se analizó el contenido de $\mathrm{Zn}$ y como referentes $\mathrm{Cd}, \mathrm{Cu}$ y $\mathrm{Pb}$. Se realizó un ataque químico para estimar el $\mathrm{Zn}$ total y un ataque secuencial para estimar "especies" o fracciones. La cuantificación se realizó en un polarógrafo POL 150, acoplado a un analizador Trace Lab 50TM, con voltametría de onda cuadrada y adición estándar. Además, se analizó la textura del sedimento, materia orgánica total, carbono orgánico total y fósforo total. Los resultados confirmaron la mayor concentración de Zn en los sedimentos superficiales de la cabeza del fiordo. Los perfiles mostraron la mayor concentración de Zn en superficie. El ataque químico secuencial indicó como fracción más abundante al Zn residual (60 a 80\%). La fracción de Zn asociada a oxi-hidróxidos y órgano-metálicos fue parecida (10 a 20\%) y mayor que los intercambiables (5 a 10\%). El Zn residual fue asociado a la fracción litogénica y el restante correspondería a aportes asociados a componentes fluviales, advectivos y antropogénicos en la cabeza del fiordo. La identificación de las vías de enriquecimiento de Zn entrega información que permitiría implementar políticas de gestión para la protección del área y hacer reconocibles los cambios por fuentes antropogénicas.

Palabras clave: estuarios, sedimentos, Zn, voltametría de redisolución anódica, fiordo Aysén, Chile.

Corresponding author: Ramón Ahumada (rahuma@ucsc.cl) 


\section{INTRODUCTION}

The sedimentary matrix, in terms of its trace metal composition, is basically made up of detrital fractions from the rocky basement along with the metallic compounds or forms converging on the site via natural (advection, aeolian or fluvial transport) and/or anthropogenic processes (pollution). From this perspective, the sediments are a complex, highly variable, and heterogeneous "sink matrix" in which sedimentary deposits are arranged in temporal layers that indicate the metal input processes.

The chemical composition of the sediments is directly influenced by processes and equilibriums occurring in the water column and in the natural sedimentation/stratification processes (Stumm \& Morgan, 1981). The sequence of sediment accumulation reveals the history of the fluctuations to which sedimentary environments are subjected (Förstner et al., 1978).

It has been suggested that the rate of removal of chemical elements increases at sites with high sedimentary accumulation due to physical and chemical changes in the sediment; the magnitude of these processes is greater in deeper sediments (Calvert, 1976). Moreover, not all the metals deposited in the sediments remain there. Rather, some fractions are released into the water column due to changes in the environmental conditions (Tessier \& Campbell, 1988).

Metal abundance studies in marine sediments consider the geological structure of the sediments and possible allochthonous sources. The sediments are a matrix that records these changes, which can then be studied through profiles or on the basis of small-scale spatial gradients. Significant problems of variance and uncertainty in such studies derive from sampling, local dynamics, conservation, and sample analyses (Birch et al., 2001) and require the use of rigorous analytical procedures and certified reference material.

Estuarine areas are highly dynamic transition zones with active chemical processes due to the change in ionic strength generated between river and sea water. The colloidal particles produced in these border zones generate sedimentary sites that are rich in metals. Additional metal deposits are transported by rivers and recorded in the sediments through the fraction that forms complexes with the particulate and colloidal material (Wen et al., 1999). On the other hand, pollution processes are local; for example, mineral shipping activities increase metal concentrations in the areas near embarkation sites.

Aysén Fjord is located in the northern sector of the southern Chilean channels $\left(45^{\circ} 20^{\prime} \mathrm{S}, 73^{\circ} 05^{\prime} \mathrm{W}\right)$. It is $\sim 75 \mathrm{~km}$ long and has a highly stratified estuarine regime (Pickard, 1971; Silva et al., 1997). The fjord is connected indirectly to the southwest coast of the Pacific Ocean via Moraleda Channel. Its geological structure is characterized by a rocky basement formed mainly of glacial erosion, alluvial and colluvial deposits and, to a lesser degree, fluvioglacial sediments, intrusive plutonic rocks, basaltic lavas, and ultrabasic rocks (SERNAGEOMIN, 2002).

The Cuervo River empties into the middle of Aysén Fjord and the head of the Aysén River, which also receives waters from the Mañiguales River. The waters from the Mañiguales River come from near the work site of Compañía Minera Contractual "El Toqui", which is located $120 \mathrm{~km}$ from the river mouth. The Condor River empties into the south-western part of the fjord head (Fig. 1). Puerto Chacabuco has been used as a shipping port for $\mathrm{Zn}$ concentrate since 1960. Between 1990 and 2001, 344,894 tons of $\mathrm{Zn}$ concentrate and 8,121 tons of $\mathrm{Pb}$ concentrate were shipped from this port. "El Toqui" planned to process 550,000 tons of concentrate and to produce 71,000 tons of $\mathrm{Zn}$ in 2005 (Gerencia, 2005).

In a study of the distribution of the total $\mathrm{Zn}$ content in the Aysén Fjord sediments, Ahumada (1998) found a vertical distribution pattern with a surface maximum and a negative gradient starting from the first $10 \mathrm{~cm}$ that stabilized in the next $15 \mathrm{~cm}$. The $\mathrm{Zn}$ concentration in the surface sediments was twice the base value of the core. This same author also found a negative concentration gradient in the surface sediments from the head to the mouth of the fjord. The total $\mathrm{Zn}$ concentration at the station located at the head of the fjord was $180 \mu \mathrm{g} \cdot \mathrm{g}^{-1}$; this decreased to $86 \mu \mathrm{g} \cdot \mathrm{g}^{-1}$ toward the mouth.

Given the total $\mathrm{Zn}$ enrichment observed in the sediments at the head of the fjord, a study of the $\mathrm{Zn}$ distribution in the fluvial and marine sediments was carried out in order to identify the main inflow points of this element in Aysén Fjord and to establish the principle causes of $\mathrm{Zn}$ enrichment in the Puerto Chacabuco sediments.

\section{MATERIALS AND METHODS}

The sampling design included the evaluation of sedi- 


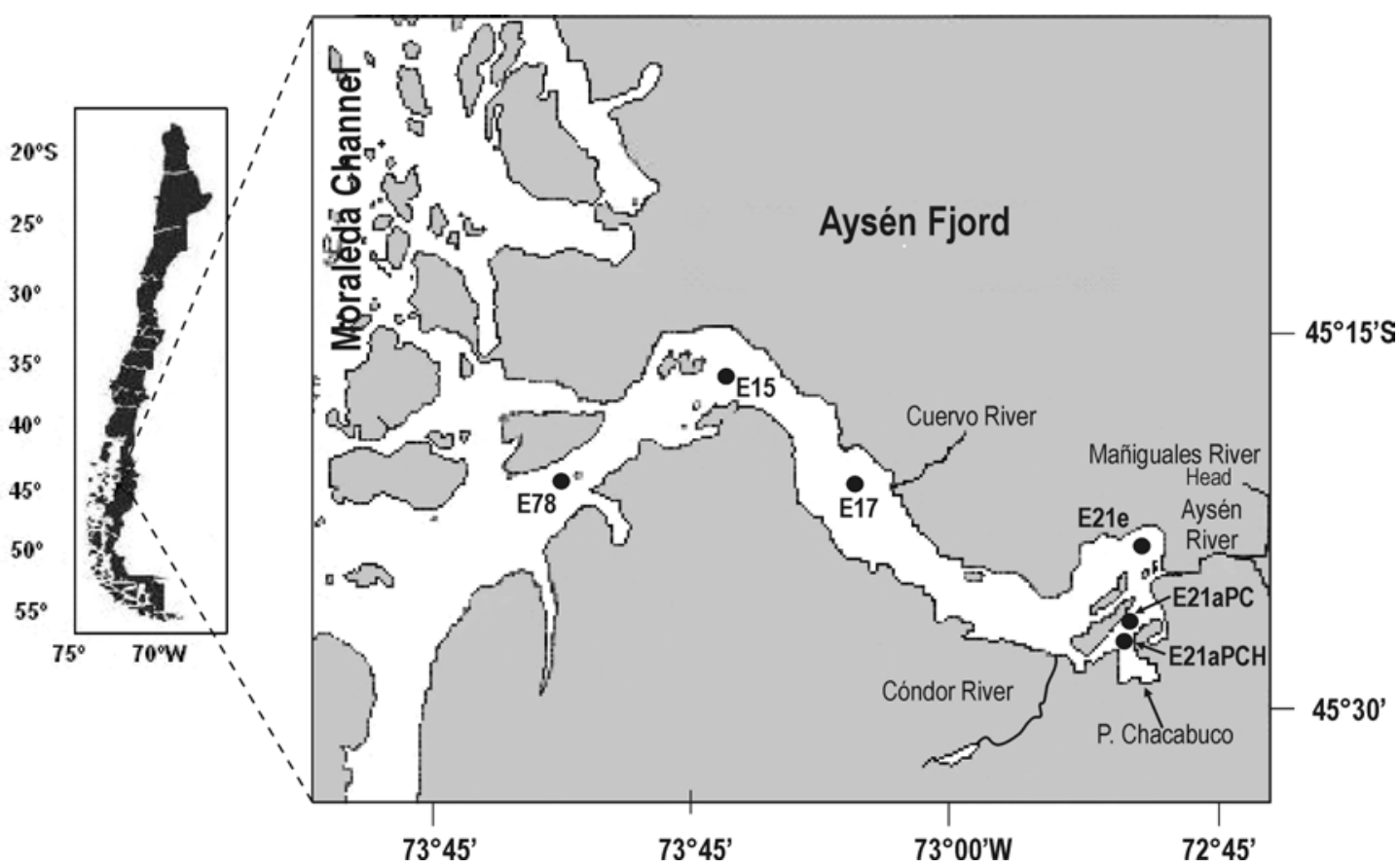

Figure 1. Map of Aysén fjord showing the location of the sampling stations of marine sediments and fluvial sediments.

ments from the Cóndor, Aysén, and Cuervo rivers (fluvial input), the head of the fjord (estuarine area), and stations along Aysén Fjord (surface concentration gradient) (Fig. 1).

Sampling was performed during the CIMAR 7 Fiordos cruise on board the AGOR "Vidal Gormaz" in November 2001. Surface sediment samples were obtained with a stainless steel box corer $(30 \mathrm{x} 30 \mathrm{x}$ $30 \mathrm{~cm}$ ). Three sub-samples were taken from the box corer sediments with PVC tubes $(5 \mathrm{~cm}$ diameter, 30 $\mathrm{cm}$ length). These were closed, labeled, and stored at $4^{\circ} \mathrm{C}$ until processing. In the laboratory, each core was cut into $2-\mathrm{cm}$ fractions every $3 \mathrm{~cm}$ along the sample. Each sample was divided into two parts: one for analyzing organic matter, organic carbon, and total phosphorus and the other for metal analyses. The sediment was dried to a constant weight, broken up in an agate mortar, homogenized in a positive laminar flow cabinet, and then stored in polyethylene bags until its analysis. The fluvial sediment samples were obtained via independent diving at the river mouths; three cores were taken from each river. These cores were subjected to the same procedure as those obtained with the box corer.

Total organic matter, total organic carbon, and total phosphorus contents were analyzed as comple- mentary variables. The total organic matter (TOM) in the sediments was determined gravimetrically as weight loss on ignition at $400 \pm 20^{\circ} \mathrm{C}$ for $12 \mathrm{~h}$ (Byers et al., 1978; Mook \& Hosking, 1982). Total organic carbon (C-org) was estimated via dichromate oxidation and back-titration of the consumption in oxidation (Gaudette et al., 1974). Although the carbon measurements were not performed with an elemental analyzer, the results are suitable for the purpose of this study. Total phosphorus (P-tot) was determined by oxidizing the different forms of phosphorus to phosphate through nitric-sulfuric digestion of the sediments and was quantified by spectrophotometry (Strickland \& Parsons, 1968).

The analysis of total metals was performed through digestion of $0.5 \mathrm{~g}$ dry sediment using a Suprapur-quality mixture of $5 \mathrm{~mL} \mathrm{HNO}_{3}, 10 \mathrm{~mL}$ $\mathrm{HF}$, and $7 \mathrm{~mL} \mathrm{HClO}_{4}$, at $70^{\circ} \mathrm{C}$ in Teflon-coated glasses. The residue was dissolved in Suprapur $\mathrm{HCl}$ and gauged to $25 \mathrm{~mL}$ with ultra pure water. The quantification was performed in a polarographic analyzer, model POL 150, coupled to a Trace Lab 50TM analyzer and an MDE 150 controller, using the standard addition method with anodic redissolution polarography through the square wave voltammetry technique. Cd was analyzed separately due to the 
difference in concentration between $\mathrm{Cd}$ and the other metals, especially $\mathrm{Zn}$.

The sequential extraction of $\mathrm{Zn}$ was performed on $1 \mathrm{~g}$ of dry sediment following the procedure of Tessier \& Campbell (1988) and Tessier et al. (1979), which consists of separating the $\mathrm{Zn}$ content into five fractions: exchangeable, carbonates, oxides and hydroxides connected to organic matter, and residuals. The methodological observations of Luoma \& Davis (1983), Rapin et al. (1986), Martín et al. (1987), and Belzile et al. (1989) were taken into consideration. During the analysis, each fraction was separated by centrifugation at $13,000 \mathrm{rpm}$ for $30 \mathrm{~min}$; the residues were washed with Milli-Q water. The $\mathrm{Zn}$ content in each one of the acid extracts was analyzed following the aforementioned procedure. The $\mathrm{Zn}$ concentration for the lowest fraction was obtained as the difference of the total concentration.

The sediment samples obtained in the rivers and Aysén Fjord were sieved through a Teflon mesh (rot-up) according to the Udden-Wentworth scale (2000 to $0.65 \mu \mathrm{m}$ ).

In order to validate the methodology applied and to estimate the analytical error in the determination of trace metals, a simultaneous analysis was done on certified reference material of marine sediments (NRC MESS-2) elaborated by the National Research Council of Canada; the same procedure was followed for this analysis.

\section{RESULTS}

The results obtained from the analysis of the certified reference material showed greater variability for $\mathrm{Zn}_{\text {total, }}$ with an analytical error close to $10 \%$; this was higher than the errors for $\mathrm{Pb}$ and $\mathrm{Cu}$. It was not possible to quantify $\mathrm{Cd}$ with routine analyses (Table 1).

The sediment grain size at the river mouths was low in the Aysén and Cuervo rivers, dominated by gravel and sand; in Cóndor River, fine sand and silt were the dominant fractions. The analysis was carried out using the finest fraction. In the first case, the fine sediment was $24 \%$ of the total sample and, in the second case, it was $65 \%$. The analytical results of the total organic matter (TOM), C-org, P-tot, and metals in the sediment samples obtained at the mouths of the main tributaries of Aysén Fjord are indicated in Table 2. The organic matter content in Condor River was much higher $(\approx 28 \%)$, with elevated C-org, P-tot, $\mathrm{Cd}$, and $\mathrm{Pb}$, but $\mathrm{Zn}$ contents were lower.

The sediment texture at the stations in Aysén Fjord differed from that of the fluvial sediments; the fjord sediments were highly selected, with more than $97 \%$ silt $(\Phi<0.65 \mu \mathrm{m})$. The TOM concentrations were very dissimilar, fluctuating between $0.42 \%$ (Sta. E15) and 7.19\% (Sta. E21-PC) (Table 3). The chemical analysis for determining metals in the sediments showed concentration values similar to those found in the region's marine sediments, although some values were higher than expected: Cd (Sta. E21e, E17), Cu (Sta. E21e, E17), and Zn (stations at the fjord head).

Table 4 summarizes the vertical distribution of the total $\mathrm{Zn}$ content in the sediment cores collected at the head of the fjord (Sta. E21-PCH). The analysis of the information shows a negative gradient in the $\mathrm{Zn}$ concentration with depth, unlike the behavior of $\mathrm{Cd}, \mathrm{Pb}$, and $\mathrm{Cu}$.

On the other hand, the fractionated attack of $\mathrm{Zn}$ in the surface sediments indicated that $\mathrm{Zn}$ is

Table 1. Estimated errors for metal determinations based on the Certified Reference Material for marine sediments (MESS-2). SD: average standard deviation from four independent measurements of standard addition, BDL: below detection limit.

\begin{tabular}{llll}
\hline \multicolumn{4}{l}{ Certified marine sediments MESS-2 } \\
\hline Metal & $\begin{array}{l}\text { Certified value } \\
\left(\boldsymbol{\mu} \cdot \mathbf{g}^{-1}\right) \pm \text { SD }\end{array}$ & $\begin{array}{l}\text { Experimental value } \\
\left(\boldsymbol{\mu} \mathbf{g} \cdot \mathbf{g}^{-1}\right) \pm \mathbf{S D}\end{array}$ & $\%$ error \\
\hline $\mathrm{Cd}$ & $0.24 \pm 0.01$ & $\mathrm{BDL}$ & - \\
$\mathrm{Cu}$ & $39.3 \pm 0.2$ & $38.10 \pm 1.2$ & 3.0 \\
$\mathrm{~Pb}$ & $21.9 \pm 1.2$ & $21.2 \pm 0.2$ & 3.2 \\
$\mathrm{Zn}$ & $172 \pm 16$ & $154.6 \pm 15.1$ & 10.1 \\
\hline
\end{tabular}


Table 2. Average concentration of total organic material (TOM), organic carbon (C-org), and total phosphorus (P-tot) in the fluvial sediments of the main rivers of Aysén Fjord. SD: standard deviation, CV: coefficient of variation.

\begin{tabular}{|c|c|c|c|c|c|c|c|c|}
\hline River & Statistics & $\begin{array}{c}\text { TOM } \\
\%\end{array}$ & $\begin{array}{c}\text { C-org } \\
\%\end{array}$ & $\begin{array}{c}\text { P-tot } \\
\left(\mu \mathrm{g} \cdot \mathrm{g}^{-1}\right)\end{array}$ & $\underset{\left(\mu \mathrm{g} \cdot \mathrm{g}^{-1}\right)}{\mathrm{Cd}}$ & $\underset{\left(\mu \mathrm{g}^{-\mathrm{g}^{-1}}\right)}{\mathrm{Cu}}$ & $\begin{array}{c}\mathrm{Pb} \\
\left(\mu \mathrm{g} \cdot \mathrm{g}^{-1}\right)\end{array}$ & $\underset{\left(\mu \mathrm{g} \cdot \mathrm{g}^{-1}\right)}{\mathrm{Zn}}$ \\
\hline \multirow[t]{3}{*}{ Aysén } & Average & 3.17 & 1.72 & 0.15 & 0.44 & 67.03 & 15.40 & 108.22 \\
\hline & SD & 0.22 & 0.07 & 0.05 & 0.21 & 5.12 & 1.04 & 8.34 \\
\hline & $\mathrm{CV}$ & 6.98 & 3.97 & 29.41 & 48.38 & 7.63 & 6.78 & 7.71 \\
\hline \multirow[t]{3}{*}{ Condor } & Average & 28.21 & 9.4 & 2.05 & 1.41 & 46.43 & 28.97 & 12.70 \\
\hline & SD & 2.75 & 0.57 & 0.31 & 0.36 & 11.71 & 5.03 & 8.74 \\
\hline & $\mathrm{CV}$ & 9.74 & 6.03 & 17.80 & 25.12 & 25.21 & 17.36 & 30.46 \\
\hline \multirow[t]{3}{*}{ Cuervo } & Average & 0.94 & 0.13 & 0.37 & 0.31 & 37.34 & 11.90 & 96.25 \\
\hline & SD & 0.08 & 0.01 & 0.11 & 0.01 & 7.45 & 0.71 & 3.61 \\
\hline & $\mathrm{CV}$ & 8.37 & 7.40 & 29.18 & 4.56 & 19.94 & 5.94 & 3.75 \\
\hline
\end{tabular}

Table 3. Concentrations of total organic materials (TOM), organic carbon (C-org), and total phosphorus (P-tot), and metals in the marine surface sediments of Aysén Fjord. SD: standard deviation, CV: coefficient of variation.

\begin{tabular}{|c|c|c|c|c|c|c|c|c|}
\hline Station & Statistics & $\begin{array}{c}\text { TOM } \\
\%\end{array}$ & $\begin{array}{c}\text { C-org } \\
\%\end{array}$ & $\begin{array}{c}\text { P-tot } \\
\left(\mu \mathrm{g} \cdot \mathrm{g}^{-1}\right)\end{array}$ & $\underset{\left(\mu \mathrm{g} \cdot \mathrm{g}^{-1}\right)}{\text { Cd }}$ & $\begin{array}{c}\mathrm{Cu} \\
\left(\mu \mathrm{g} \cdot \mathrm{g}^{-1}\right)\end{array}$ & $\begin{array}{c}\mathrm{Pb} \\
\left(\mu \mathrm{g} \cdot \mathrm{g}^{-1}\right)\end{array}$ & $\begin{array}{c}\mathrm{Zn} \\
\left(\mu \mathrm{g} \cdot \mathrm{g}^{-1}\right)\end{array}$ \\
\hline \multirow[t]{3}{*}{ E21-PCH } & Average & 5.74 & 2.31 & 1.07 & 0.35 & 27.15 & 15.81 & 116.53 \\
\hline & SD & 1.48 & 0.37 & 0.28 & 0.03 & 3.62 & 1.03 & 10.55 \\
\hline & $\mathrm{CV}$ & 25.72 & 15.90 & 26.13 & 8.81 & 13.35 & 6.50 & 9.05 \\
\hline \multirow[t]{3}{*}{ E21-PC } & Average & 7.19 & 1.90 & 1.17 & 0.37 & 27.60 & 18.74 & 120.31 \\
\hline & SD & 0.66 & 0.33 & 0.31 & 0.06 & 3.48 & 1.02 & 6.25 \\
\hline & $\mathrm{CV}$ & 9.18 & 17.10 & 26.62 & 16.87 & 12.61 & 5.46 & 5.19 \\
\hline \multirow[t]{3}{*}{ E21e } & Average & 4.13 & 1.73 & 0.78 & 1.35 & 55.10 & 32.23 & 76.53 \\
\hline & SD & 0.16 & 0.21 & 0.40 & 0.06 & 16.03 & 3.00 & 13.66 \\
\hline & $\mathrm{CV}$ & 3.86 & 12.34 & 51.74 & 4.72 & 29.10 & 9.32 & 17.84 \\
\hline \multirow[t]{3}{*}{ E17 } & Average & 4.16 & 1.72 & 0.88 & 0.69 & 69.57 & 14.53 & 109.06 \\
\hline & SD & 0.36 & 0.07 & 0.28 & 0.33 & 15.02 & 2.97 & 15.93 \\
\hline & $\mathrm{CV}$ & 8.69 & 3.97 & 32.15 & 47.19 & 21.60 & 20.46 & 14.61 \\
\hline \multirow[t]{3}{*}{ E15 } & Average & 0.42 & 0.11 & 0.22 & 0.47 & 25.85 & 14.90 & 86.66 \\
\hline & SD & 0.10 & 0.01 & 0.04 & 0.08 & 3.93 & 2.12 & 10.06 \\
\hline & $\mathrm{CV}$ & 22.80 & 12.42 & 17.10 & 16.73 & 15.22 & 14.24 & 11.61 \\
\hline
\end{tabular}


Table 4. Average concentration of trace metals for the different layers of the Aysén Fjord sediments. SD: standard deviation, CV: coefficient of variation.

\begin{tabular}{llcccc}
\hline Layer & Statistics & $\begin{array}{c}\mathbf{C d} \\
\left(\boldsymbol{\mu} \mathbf{g} \cdot \mathbf{g}^{-\mathbf{1}}\right)\end{array}$ & $\begin{array}{c}\mathbf{P b} \\
\left(\boldsymbol{\mu} \cdot \mathbf{g}^{-\mathbf{1}}\right)\end{array}$ & $\begin{array}{c}\mathbf{Z n} \\
\left(\boldsymbol{\mu} \cdot \mathbf{g}^{-\mathbf{1}}\right)\end{array}$ & $\begin{array}{c}\mathbf{C u} \\
\left(\boldsymbol{\mu} \mathbf{g} \cdot \mathbf{g}^{-\mathbf{1}}\right)\end{array}$ \\
\hline $0-2 \mathrm{~cm}$ & Average & 0.95 & 56.95 & 25.95 & 119.06 \\
& SD & 0.48 & 21.23 & 9.04 & 33.68 \\
& CV & 50.21 & 37.28 & 34.82 & 35.43 \\
$4-6 \mathrm{~cm}$ & Average & 0.96 & 55.92 & 27.30 & 107.79 \\
& SD & 0.74 & 37.61 & 11.07 & 25.98 \\
& CV & 76.71 & 67.27 & 40.57 & 24.10 \\
$10-12 \mathrm{~cm}$ & Average & 1.22 & 55.83 & 35.40 & 103.33 \\
& SD & 0.47 & 29.74 & 21.73 & 35.57 \\
& CV & 38.23 & 53.27 & 61.37 & 34.42 \\
$15-17 \mathrm{~cm}$ & Average & 0.38 & 42.41 & 26.33 & 92.12 \\
& SD & 0.31 & 7.12 & 5.96 & 10.24 \\
& CV & 81.58 & 16.79 & 22.64 & 11.12 \\
\hline
\end{tabular}

most abundant in the residual fraction at all the stations along the fjord, independently of the total concentration. In order to highlight this characteristic and indicate the greater importance of the relative $\mathrm{Zn}$ concentration for this fraction, the chemical compounds or Zn "species" for each sample are indicated in percentages (Fig. 2).

\section{DISCUSSION}

Trace metals naturally exist in low concentrations. Some of them are close to the detection limit of the measurement techniques, making the use of a reference necessary in order to determine the analytical error of the measurements. The analysis of the significance of the $\mathrm{Zn}$ content showed that the differences observed between the experimental value and the certified MESS-2 ( $p>0.05$ ) were not statistically significant. Likewise, the percentage of the error estimated for the $\mathrm{Cu}$ measurements was $3.0 \%$, for $\mathrm{Pb} 3.2 \%$, and for $\mathrm{Zn} 10.1 \%$, all acceptable levels in environmental studies (Birch et al., 2001).

In Aysén Fjord, river mouth and marine sediments differed in grain size as well as in carbon content and organic matter, as possible absorbent substances and/ or compounds or forms that capture metals. These variables showed lesser changes along the fjord's longitudinal distribution component. For example, at the mouths of the Aysén (Sta. E21e) and Cuervo (Sta. E17) rivers, inappropriately classified sediments were found whose main components were gravel, pebble, and coarse sand. The TOM concentration was average in Aysén River but low in Cuervo River. Both these rivers presented similar $\mathrm{Pb}$ and $\mathrm{Cd}$ contents, but the $\mathrm{Cu}$ content in Cuervo River was twice that of Aysén River (Table 2).

The sediments in Cóndor River were $28 \%$ fine sand and $72 \%$ silt, with high concentrations of organic matter, total $\mathrm{Cd}$, and total $\mathrm{Pb}$. The low $\mathrm{Zn}$ concentration recorded in the sediments was noteworthy, being anomalous for the region. The $\mathrm{Zn}$ concentration in the Aysén River sediments, entering at the fjord's head, was slightly higher than that registered in Cuervo River. Aysén River is an affluent of the Mañiguales River; the latter river's head waters run near a mining operation. The course of Cuervo River, however, is farther away and its waters enter at the middle of the fjord, so it could be considered to have typical $\mathrm{Zn}$ values for the region.

Aysén Fjord showed a good selection of marine sediments, with characteristically silty clay less than $0.65 \mu \mathrm{m}$ in diameter. The highest TOM percentage was registered at the head of the fjord with a gradient towards the mouth; this situation has also been found in other fjords in the region (Silva \& Prego, 

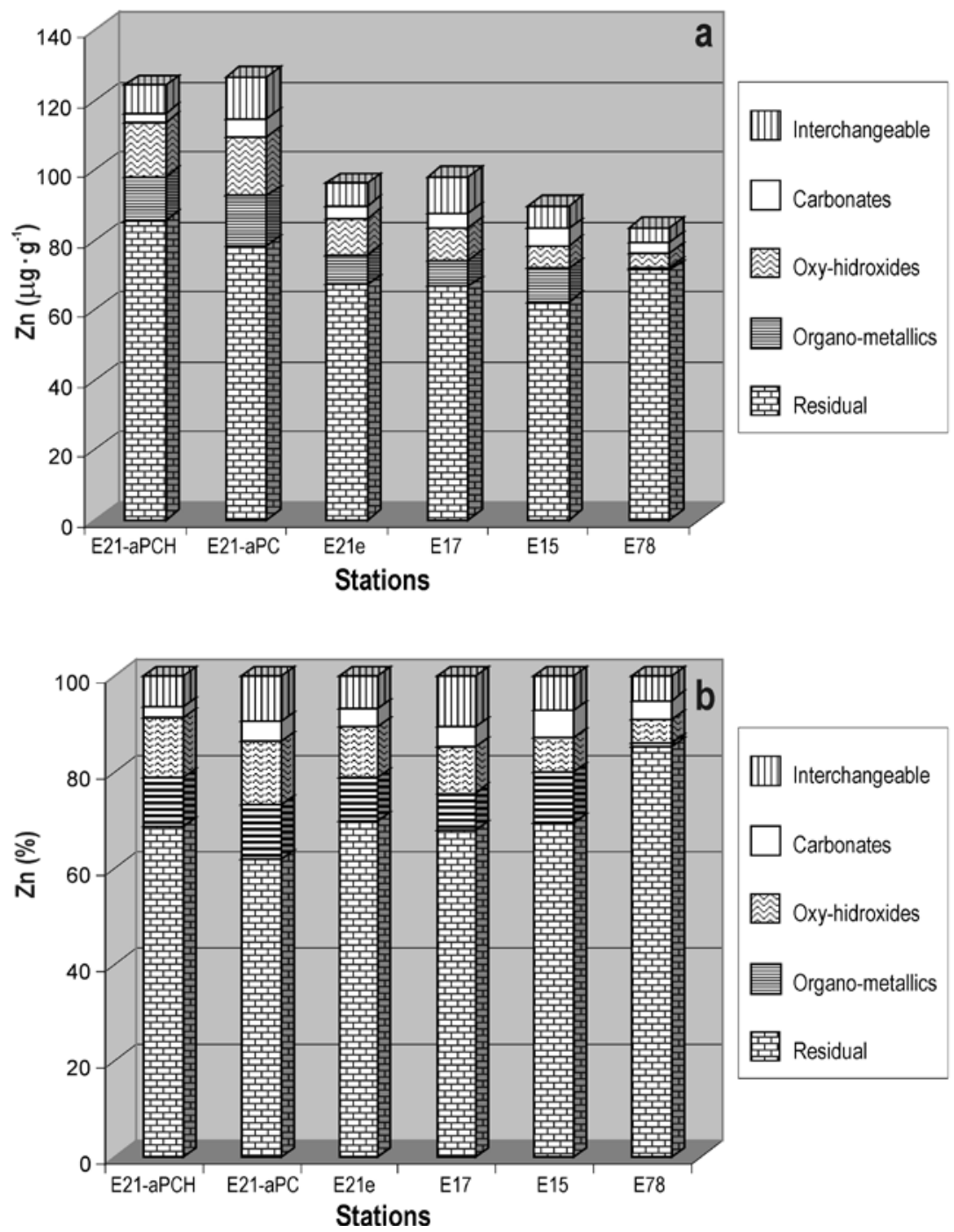

Figure 2. Abundance of Zn chemicals compounds or Zn species in sediments of Aysén fjord. a) Zn species concentration, b) Species of $\mathrm{Zn}$ in percentage for total concentration of each station (Ahumada et al., 2004).

2002). The highest $\mathrm{Zn}$ concentration coincided with the highest TOM concentration at Puerto Chacabuco, which is far from the mouth of the Aysén River. However, it is important to mention that, despite the differences in grain size, TOM, and C-org between the sediments of the Aysén and Cuervo Rivers, their $\mathrm{Zn}$ concentrations were similar. Both rivers may be acting as important $\mathrm{Zn}$ sources at the head of the fjord. This situation is confirmed at Station E17, the closest to Cuervo River (Table 3).

The $\mathrm{Zn}$ values in the fjord presented a negative gradient from Puerto Chacabuco to the mouth of the fjord. Therefore, the highest $\mathrm{Zn}$ concentration at Station E21-CH (Puerto Chacabuco) seemed to correspond to the $\mathrm{Zn}$ input coming from the miningshipping activity. Independently of this $\mathrm{Zn}$ enrichment at Puerto Chacabuco, the range of $\mathrm{Zn}$ contents could be defined as slightly higher than normal but similar to those reported for a pristine area (Ahumada \& Rudolph, 2004). Likewise, metal concentrations $(\mathrm{Cd}, \mathrm{Cu}, \mathrm{Pb}, \mathrm{Zn})$ were similar to those measured by Loring \& Asmund $(1989,1996)$ and Rasmussen (1996) in the fjords of Greenland, in the Northern Hemisphere.

The $\mathrm{Zn}$ enrichment factor in the sediments of Aysén Fjord $\left(\mathrm{EF}=\left[\mathrm{M}^{+} / \mathrm{MO}\right]_{\mathrm{Obs} .} /\left[\mathrm{M}^{+} / \mathrm{MO}\right]_{\mathrm{LB}}\right)$ was less than $2(\mathrm{EF}<2)$. For that, $\mathrm{Zn}$ concentrations normalized to organic matter were used. According 
to Birch et al. (2001), an EF < 2 does not necessarily indicate an enrichment process in the area, but rather environmental heterogeneity and variability in the sampling itself. On the other hand, the EF for the $\mathrm{Zn}$ concentration was calculated using information obtained in 1995 (CIMAR 1 Fiordos); this EF was found to be at the limit of an enrichment process $(E F \geq 2)$. These concentrations were lower than the contents determined in this study, possibly associated with sediment remobilization or the implementation of environmental management measures in the Puerto Chacabuco area.

A sediment profile was also used to analyze the $\mathrm{Zn}$ concentrations at the head of the fjord (i.e., Sta. 21-PCH). This showed high zinc concentrations in the surface sediments that decreased towards the deeper sediments (Table 4), confirming the results of Ahumada (1998) indicating that the $\mathrm{Zn}$ input in the area comes from recent anthropogenic activities (i.e., mining).

Moreover, the $\mathrm{Pb}$ content at the head of the fjord showed lower values than those found by Ahumada (1998). The $\mathrm{Pb}$ content was only higher at the station near the mouth of the Aysén River (Sta. 21e), corresponding to a $\mathrm{Pb}$ accumulation possibly transported by the Aysén River or remobilized from the Puerto Chacabuco sediments. This last option is not very probable due to the distance and depth of the fjord.

A third method used in this study was sequential extraction analysis, which is an approach that permits understanding the behavior of the chemical species that constitute the total concentration of a metal in the sediment, i.e., geochemical processes. This method, however, is limited with regard to the remobilization and reactivity occurring during the analysis (Howard \& Vandenbrink, 1999).

The species fractionation analysis of surface sediments was carried out at the deep stations ( $>60$ $\mathrm{m})$ where changes in water column salinity are not relevant since this "highly stratified" estuary has a halocline in the upper $25 \mathrm{~m}$ and a quasi homohaline layer below $50 \mathrm{~m}$ (Silva et al., 1998). The dissolved oxygen concentration exceeded $20 \%$, which implies non reductive conditions (positive Eh $>100 \mathrm{mV}$ ); therefore, the changes caused by possible modifications in $\mathrm{pH}$ and Eh are not relevant. Thus, an approximation was obtained in which the permanent or refractory fractions and the recently added fractions are not changing; this made it possible to recognize fractions that are exchangeable or available in the sedimentary system.
The results of the fractionation of the $\mathrm{Zn}$ species (at stations 21-PCH at the head of the fjord and E15 at the mouth) showed a $\mathrm{Zn}$ concentration of 60-80 $\mathrm{ug}^{-\mathrm{g}^{-1}}$ (Fig. 2a) in the residual fraction, which is equivalent to $60 \%$ of the total (Fig. 2b). The sequence of $30 \%$ of the remaining fractions showed $\mathrm{Zn}$ abundance order associated with oxy-hydroxides $>$ organo-metallics $>$ exchangeable $>$ carbonates.

According to the location of the stations, expressed in percentages (Fig. 2b), the values of the fractions showed that the zinc associated with oxyhydroxides, organo-metallics, and carbonates was higher at the head of the fjord than at the mouth. This is reasonable, since the $\mathrm{Zn}$ entering the sea water would preferably form complexes and oxyhydroxides.

The zinc content in the sediments comes mainly from the rocky basement. In Aysén Fjord, the sedimentary origins are likely to be mixtures of clasts of basaltic and metamorphic rocks (i.e., granites and schists). The average value reported for $\mathrm{Zn}$ in basaltic rocks is $105 \mu \mathrm{g} \cdot \mathrm{g}^{-1}$, for schists $95 \mu \mathrm{g} \cdot \mathrm{g}^{-1}$, and for granites $50 \mu \mathrm{g} \cdot \mathrm{g}^{-1}$ (Libes, 1992). This indicates that the baseline value of $\mathrm{Zn}$ at the mouth of Aysén Fjord is $86 \mu \mathrm{g} \cdot \mathrm{g}^{-1}$ (Ahumada, 1998); this value results from the proportionality of mother rocks plus detrital components of fluvial origin and biogenic and autigenic components (Buffle, 1988). At the head of the fjord, the $\mathrm{Zn}$ baseline value is $95.92 \mu \mathrm{g} \cdot \mathrm{g}^{-1}$, to which possible anthropogenic components must be added (Ahumada, 1989). This agrees with the average $\mathrm{Cd}$, $\mathrm{Cu}$, and $\mathrm{Pb}$ contents measured at the fjord stations that have similar magnitudes and are proportional to the original rocky basement (Libes, 1992).

Globally, the main sources producing changes in the $\mathrm{Zn}$ input on the planet are the mining industry (57\%), fluvial contributions ( $25 \%$ ), and atmospheric contributions (9\%) (Libes, 1992). Using this general approach, and considering that the measurable effects are local, it is possible to recognize a residual fraction corresponding to sediment-producing rocks. Based on this, it is possible to establish changes according to the concentrations associated with the sites and characteristics of the sedimentation areas. Thus, the $\mathrm{Zn}$ concentration at the mouth of the fjord corresponds mainly to the detrital component of the rocky basement and represents the natural value. Hence, at station E17 the main identifiable element is the fluvial contribution (Cóndor River) and at station E21-PCH an anthropogenic component is added. The magnitudes of the advective processes in Aysén Fjord 
are less than $5 \%$ of the total concentration, which is evident in the concentration gradients.

\section{Final considerations}

According to the analysis performed, we can infer that the main sources of trace metals in the sediments of Aysén Fjord are:

a) The regional basaltic and metamorphic basement, which contributes $\mathrm{Zn}$ concentrations close to 80.0 $\mu \mathrm{g} \cdot \mathrm{g}^{-1}$ of the total $\mathrm{Zn}$, i.e., approximately 60 to $80 \%$.

b) Contributions generated by rock leaching and atmospheric contributions from the Aysén and Cóndor rivers that increase the $\mathrm{Zn}$ concentration from 10 to $15 \%$.

c) Mining activity in the form of shipping concentrates helps to increase local concentrations at Puerto Chacabuco by approximately $20-30 \%$.

d) The $\mathrm{Zn}$ components or dominant forms in the fjord sediments are related to residuals (ca. 70\%), oxy-hydroxides, and organo-metallic compounds, both close to $20 \%$, indicating that the lesser fractions correspond mainly to fluvial detritus and biogenic fractions with concentrations up to $10 \%$.

e) The fractions of exchangeable $\mathrm{Zn}$ and $\mathrm{Zn}$ associated with carbonates, the most unstable and available fractions in the system and increased less than $5 \%$ over the natural value at the mouth of the fjord.

f) The highest $\mathrm{Zn}$ concentrations measured in Aysén Fjord, up to $50 \%$ over the baseline value, do not constitute an element of environmental risk (Birch et al., 2001), so there is no impact on the sediments, although environmental monitoring programs are necessary.

\section{ACKNOWLEDGMENTS}

We thank the Comité Oceanográfico Nacional (CONA) for financing the research project CONA C7F 01-02, corresponding to the CIMAR 7 Fiordos cruise; the Facultad de Ciencias of the Universidad Católica de la Santísima Concepción for administrative contributions, laboratories, and human resources; and the MECESUP UCSC-9901 project, which allowed the use of high-precision equipment, thereby furthering the development of the discipline.

\section{REFERENCES}

Ahumada, R. 1998. Metales traza (Ba, Cd, $\mathrm{Co}, \mathrm{Cr}, \mathrm{Ni}$, $\mathrm{Pb}, \mathrm{V}$ y $\mathrm{Zn}$ ) en los sedimentos del Seno Aysén: Línea base y alteraciones ambientales. Cienc. Tecnol. Mar, 21: 73-86.

Ahumada, R. \& A. Rudolph. 2004. Trace metals and other constitutive components in two sediment cores from a remote glacier-fed estuarine lagoon in southern Chile. Estuar. Coast. Shelf Sci., 59(2): 231-236.

Ahumada, R., E. González \& J.Y. Neira. 2004. Especiación de $\mathrm{Zn}$ en sedimentos marinos del fiordo Aysén. Invest. Mar., Valparaíso, 32(1): 3-10.

Belzile, N., P. Lecompte \& A. Tessier. 1989. Testing readsortion of trace elements during chemical extractions of bottom sediments. J. Environ. Sci. Technol., 23(8): 1015-1020.

Birch, G.F., S.E. Taylor \& C. Matthai. 2001. Small scale spatial and temporal variance in the concentration of heavy metals in aquatic sediments: a review and some new concepts. Environ. Pollut., 113: 357-372.

Byers, Sch., C.E.L. Mills \& P.L. Steward. 1978. A comparison of methods of determining organic carbon in marine sediments with suggestions for a standard method. Hidrobiologia, 58(1): 43-47.

Buffle, J. 1998. Complexation reactions in aquatic systems. Ellis Horwood Limited, Halted Press, Chichester, 692 pp.

Calvert, S.E. 1976. The mineralogy and geochemistry of near-shore sediments. In: J.P. Riley \& R. Chester (eds.). Chemical Oceanography. Academic Press, New York, pp. 187-280.

Förstner, U., G. Müller \& P. Stoffers. 1978. Heavy metals contamination in estuarine and coastal sediment: source, chemical association and diagenetic effects. In: Biogeochemistry of estuarine sediments. Proceeding of UNESCO/Scor Workshop. UNESCO, Paris, pp. 49-69.

Gaudette, H., W. Flight, L. Toner \& D. Foldger. 1974. An inexpensive titration method for the determination of organic carbon in recent sediments. J. Sediment. Res., 44(1): 249-253.

Gerencia. 2005. Compañía Minera El Toqui y ADL. Superando la barrera del aislamiento con tecnología Novell. www.emb.cl/gerencia/articulo. mv? sec $=3 \&$ num $=75 \& \mathrm{mag}=1 \&$ wmag $=22$. Revised: 8 May 2007.

Howard, J.L. \& W.J. Vandenbrink. 1999. Sequential extraction analysis of heavy metals in sediments of variable composition using nitilotriacetic acid 
to counteract resortion. Environ. Pollut., 106: 285-292.

Libes, S.M. 1992. An introduction to marine biogeochemistry. John Wiley \& Sons, New York, 734 pp.

Loring, D.H. \& G. Asmund. 1989. Heavy metals contamination of a Greenland fjord system by mine waste. Environ. Geol. Water Sci., 14: 61-71.

Loring, D.H. \& G. Asmund. 1996. Geochemical factors controlling accumulation of major and trace elements in Greenland coastal and fjord sediments. Environ. Geol., 28(1): 2-11.

Luoma, S.N. \& J.A. Davis. 1983. Requirements for modelling trace metal partitioning in oxidized estuarine sediments. Mar. Chem., 12: 159-181.

Martin, J.M., P. Nirel \& A.J. Thomas. 1987. Sequential extraction techniques: promises and problems. Mar. Chem., 22: 313-341.

Mook, D. \& C. Hoskin. 1982. Organic determinations by ignition: caution advised. Estuar. Coast. Shelf Sci., 15: 697-699.

Pickard, G. 1971. Some physical oceanographic features of inlets of Chile. J. Fish. Res. Bd. Canada, 28: 1077-1106.

Rasmussen, P.E. 1996. Trace metals in the environment: a geological perspective. Geological Survey of Canada. Bulletin, 429: 1-26.

Rapin, F., A. Tessier, P.G.C. Campbell \& R. Carignan. 1986. Potential artifacts in the determination of metal partitioning in sediments by sequencial extraction procedure. J. Environ. Sci. Technol., 20(8): 836-840.

Servicio Nacional de Geología y Minería (SERNAGEOMIN). 2002. Mapa Geológico de Chile, $N^{\circ} 5$. Servicio Nacional de Geología y Minería. Escala 1:1000000.
Silva, N., C. Calvete \& H. Sievers. 1997. Características oceanográficas físicas y químicas de canales australes chilenos entre Puerto Montt y laguna San Rafael (Crucero CIMAR 1 Fiordo). Cienc. Tecnol. Mar, 20: 23-106.

Silva, N., C. Calvete \& H.A. Sievers. 1998. Masas de agua y circulación general para algunos canales australes entre Puerto Montt y laguna San Rafael, Chile (Crucero CIMAR 1 Fiordo). Cienc. Tecnol. Mar, 21: 17-48.

Silva, N. \& R. Prego. 2002. Carbon and nitrogen spatial segregation and stoichiometry in the surface sediments of southern Chilean inlets $\left(41^{\circ}-56^{\circ} \mathrm{S}\right)$. Estuar. Coast. Shelf Sci., 55: 763-775.

Strickland, J.H.D. \& T.R. Parsons. 1968. A practical handbook of seawater analysis. Fish. Res. Bd. Can. Bull., 167: 310 pp.

Stumm, W. \& J.J. Morgan. 1981. Aquatic chemistry: an introduction emphasizing chemical equilibrium in natural waters. A Wiley Interscience Publication, New York, 780 pp.

Tessier, A. \& P.G.C. Campbell \& M. Bisson. 1979. Sequential extraction procedure for the speciation of particulate trace metals. Anal. Chem., 51: 844-851.

Tessier, A. \& P.G.C. Campbell. 1988. Partitioning of trace metals in sediments. In: J. Kramer \& H. Allen (eds.). Metal speciations: theory, analysis and application. Lewis Publishers, Chelsea, pp.183-199.

Wen, L.S., P. Santschi, G. Gill \& C. Paternostro. 1999. Estuarine trace metal distributions in Galveston Bay: importance of colloidal form in speciation of dissolved phase. Mar. Chem., 63: 185-212. 